Cool Conduct 
This page intentionally left blank 
WEIMAR AND NOW: GERMAN CULTURAL CRITICISM Edward Dimendberg, Martin Jay, and Anton Kaes, General Editors

I. Heritage of Our Times, by Ernst Bloch

2. The Nietzsche Legacy in Germany, I890-I990, by Steven E. Aschheim

3. The Weimar Republic Sourcebook, edited by Anton Kaes, Martin Jay, and Edward Dimendberg

4. Batteries of Life: On the History of Things and Their Perception in Modernity, by Christoph Asendorf

5. Profane Illumination: Walter Benjamin and the Paris of Surrealist Revolution, by Margaret Cohen

6. Hollywood in Berlin: American Cinema and Weimar Germany, by Thomas J. Saunders

7. Walter Benjamin: An Aesthetic of Redemption, by Richard Wolin

8. The New Typography, by Jan Tschichold, translated by Ruari McLean

9. The Rule of Law under Siege: Selected Essays of Franz L. Neumann and Otto Kirchheimer, edited by William E. Scheuerman

Io. The Dialectical Imagination: A History of the Frankfurt School and the Institute of Social Research, I923-I950, by Martin Jay

I I. Women in the Metropolis: Gender and Modernity in Weimar Culture, edited by Katharina von Ankum

I 2. Letters of Heinrich and Thomas Mann, I900-I949, edited by Hans Wysling, translated by Don Reneau

I3. Empire of Ecstasy: Nudity and Movement in German Body Culture, I9I0-I935, by Karl Toepfer

I4. In the Shadow of Catastrophe: German Intellectuals between Apocalypse and Enlightenment, by Anson Rabinbach

I 5. Walter Benjamin's Other History: Of Stones, Animals, Human Beings, and Angels, by Beatrice Hanssen

16. Exiled in Paradise: German Refugee Artists and Intellectuals in America from the I930s to the Present, by Anthony Heilbut

17. Cool Conduct: The Culture of Distance in Weimar Germany, by Helmut Lethen, translated by Don Reneau

I 8. In a Cold Crater: Cultural and Intellectual Life in Berlin, I945-1948, by Wolfgang Schivelbusch, translated by Kelly Barry

I9. A Dubious Past: Ernst Jünger and the Politics of Literature after Nazism, by Elliot Y. Neaman 
20. Beyond the Conceivable: Studies on Germany, Nazism, and the Holocaust, by Dan Diner

2I. Prague Territories: National Conflict and Cultural Innovation in Franz Kafka's Fin de Siècle, by Scott Spector

22. Munich and Memory: Architecture, Monuments, and the Legacy of the Third Reich, by Gavriel D. Rosenfeld

23. The UFA Story: A History of Germany's Greatest Film Company, I9I 81945, by Klaus Kreimeier, translated by Robert and Rita Kimber

24. From Monuments to Traces: Artifacts of German Memory, I870-I990, by Rudy Koshar

25. We Weren't Modern Enough: Women Artists and the Limits of German Modernism, by Marsha Maskimmon

26. Culture and Inflation in Weimar Germany, by Bernd Widdig

27. Weimar Surfaces: Urban Visual Culture in I920s Germany, by Janet Ward 


\section{Cool Conduct}

The Culture of Distance in Weimar Germany

\section{Helmut Lethen}

Translated by Don Reneau

UNIVERSITY OF CALIFORNIA PRESS

Berkeley · Los Angeles · London 
The translations of Bertolt Brecht's "Report on a Tick" (chapter I) and "On the Infanticide Marie Farrar" (chapter 6) are from Bertolt Brecht Poems, I913-I956, ed. John Willett and Ralph Manheim (New York: Methuen, I976). They are reproduced by permission of Suhrkamp Verlag, Frankfurt am Main.

University of California Press Berkeley and Los Angeles, California

University of California Press, Ltd.

London, England

(C) 2002 by

The Regents of the University of California

\section{Lethen, Helmut.}

[Verhaltenslehren der Kälte. English]

Cool conduct : the culture of distance in Weimar Germany / Helmut Lethen ; translated by Don Reneau.

p. cm. - (Weimar and now ; I7)

Includes bibliographical references and index. ISBN 0-520-20IO9-4 (alk. paper)

I. Conduct of life. I. Title. II. Series.

BJI 583 .L 57 I 32002

$943.085-\mathrm{dc} 2 \mathrm{I}$

2001027679

Manufactured in the United States of America

$\begin{array}{llllllllll}\text { II } & \text { IO } & 09 & 08 & 07 & 06 & 05 & 04 & 03 & 02\end{array}$

I0 $\quad \begin{array}{lllllllll}8 & 8 & 7 & 6 & 5 & 4 & 3 & 2 & \text { I }\end{array}$

The paper used in this publication meets

the minimum requirements of ANSI/NISO Z39. 48-I992 (R I997) (Permanence of Paper). () 